\title{
QUAL É A GRAÇA? O HUMOR COMO ESTRATÉGIA DE LIBERDADE NA SOCIEDADE CONTEMPORÂNEA
}

\author{
Sabrina Demozzi ${ }^{1}$
}

\begin{abstract}
Resumo
O presente artigo busca debater algumas manifestações do humor no jornalismo brasileiro a partir de características conceituais como o jornalismo alternativo, a carnavalização pelo humor e o chiste. A partir da ideia do humor como ação libertária para o questionamento da autoridade e dos discursos de verdade, busca-se dialogar com conceitos como o de vida-artista proposto por Michel Foucault, para quem a autonomia do pensamento seria uma estratégia de liberdade na sociedade contemporânea. O enfoque parte principalmente de pequenos exemplos analisados em jornais e sites que têm sua importância reconhecida nos períodos analisados.
\end{abstract}

Palavras-chave: Jornalismo, humor, liberdade de expressão.

\begin{abstract}
The aim of this article is to discuss some manifestations of humor in Brazilian journalism regarding conceptual characteristics such as alternative journalism and carnivalization by humor and wit. Taking the idea of humor as a libertarian action in order to question authority and truth into the discourses, we seek to make use of concepts such as the life-artist, suggested by Michel Foucault, for whom autonomy of thought is a strategy of freedom in contemporary society. The focus of this discussion is set off mostly by small examples analyzed in newspapers and internet websites, which were well known when they were published.
\end{abstract}

Keywords: Journalism, humor, freedom of expression.

\section{Introdução}

O título deste artigo pode suscitar à primeira vista uma interpretação de que o texto que se segue tratará o humor como mais uma solução apresentada por revistas e livros de autoajuda que condicionam os sujeitos a seguirem modelos de comportamento considerados ideais para o convívio em sociedade. Não é esta a intenção, até mesmo porque compreendemos o humor como uma ferramenta capaz de inverter esta ordem, desconstruir poderes e lugares estabelecidos.

O tema nos desperta interesse há bastante tempo, e recentemente pudemos vislumbrar possibilidades de diálogos com outras disciplinas que podem nos ajudar a ampliar a discussão sobre o humor. Este artigo revisita o tema tratado no trabalho de conclusão do curso de jornalismo da Universidade Positivo em 2006, intitulado "Humor e Informação em textos do Pasquim e de José Simão". Buscou-se fazer um estudo comparativo entre as diferentes expressões do humor como crítica no jornalismo brasileiro nos períodos compreendidos entre a década de 1970 e os anos 1990. Passados

\footnotetext{
${ }^{1}$ Jornalista (Universidade Positivo), mestranda em História (Universidade Federal do Paraná).
} 
alguns anos após este trabalho, percebemos a necessidade de analisar a expressão do humor no contexto da sociedade contemporânea, considerando as transições ocorridas no Brasil principalmente no que diz respeito à produção e circulação de informações.

Estruturamos este texto na busca de trazer um breve contexto histórico do humor analisado em $O$ Pasquim e as suas características, algumas conceituações importantes sobre o humor analisadas, sobretudo por Sigmund Freud, Vladimir Propp e Henri Bergson, alguns exemplos encontrados em sites como o Sensacionalista: um jornal isento de verdade, o blog The Piauí Herald, da revista Piauí, e outros. Finalmente, situaremos esta análise nos estudos de Michael Foucault referentes às estéticas de existência em que buscaremos traçar uma linha de debate entre este tema e o humor como estratégia de se viver em liberdade.

\section{O humor libertário no contexto da imprensa alternativa: $O$ Pasquim}

Optamos por trazer as características do jornal $O$ Pasquim por compreendermos que ele se adéqua ao que entendemos por humor libertário, ou seja, aquele "humor pelo humor" que não tem necessariamente vínculo ideológico. Além disso, é importante considerarmos que o periódico surge num momento de forte repressão às liberdades individuais e cerceamento à liberdade de imprensa. Neste contexto de significativas mudanças políticas, sociais e culturais (1964-1985) surgem diversos periódicos de contestação no Brasil e também jornalistas e escritores que apostaram no humor como uma forma libertária de atuação política.

O Pasquim, nascido de uma ideia gestada em bares cariocas, aparece de maneira informal, e no início não era levado a sério pelos seus idealizadores. Segundo um dos criadores, Jaguar, ao referir-se ao nome do jornal, Pasquim foi a melhor escolha: "Que tal Pasquim? Propus. Vão nos chamar de pasquim (jornal difamador, folheto injuriador), terão de inventar outros nomes para nos xingar." Ele surge no mais conturbado período da ditadura militar, e começa a circular no dia 26 de junho de 1969 com uma tiragem inicial de 20 mil exemplares até alcançar em 1971 a marca de 250 mil cópias.

O jornal $O$ Pasquim se enquadra na categoria da imprensa "alternativa", e de acordo com Bernardo Kucinski, a palavra "alternativa” já era usada nos Estados Unidos e na Inglaterra no movimento de contracultura e era usada para "designar arte e cultura não convencionais” e foi aplicada à imprensa por Alberto Dines, em janeiro de 1969. 


\begin{abstract}
O fenômeno da imprensa alternativa acompanha o processo da história da imprensa no Brasil, nas manifestações dos pasquins satíricos e panfletários do período da Regência e dos jornais anarquistas de operários no período de 1880-1920. Os jornais de fabricação rudimentar, muitas vezes feita por um homem só e sem fins mercantis, como era o caso de muitos pasquins, eram destinados à classe civil e aos funcionários das indústrias. Desse modo assemelham-se à imprensa alternativa da década de 70. A imprensa alternativa, neste sentido, pode ser vista como uma sucessora da imprensa panfletária dos pasquins e da imprensa anarquista, na função social de contestação, de criação de uma maneira crítica de pensamento e contrahegemônica (KUCINSKI, 1998, p.179).
\end{abstract}

Além das atitudes comuns de negação à cultura dominante, "alternativa" também significa a opção entre duas coisas "reciprocamente excludentes" citando Kucinski, e representaria a única saída para situações de adversidade e o desejo de transformação. Mesmo que o papel dos jornalistas da imprensa alternativa tenha sido o de representar heróis no combate à ditadura militar, no caso dos jornalistas de $O$ Pasquim, eles não se viam como os protagonistas de uma revolução.

\footnotetext{
Viam-se como jornalistas comuns, vivendo as circunstâncias de seu tempo, e para os quais "livre-pensar é só pensar", como definiu Millôr Fernandes. Apenas uma minoria de jornalistas engajou-se diretamente na imprensa alternativa, mas os humoristas, cartunistas e chargistas engajaram-se em massa como categoria, incluindo-se todos os grandes da época - Henfil, Ziraldo, Claudius, Jaguar, Trimano e Millôr (KUCINSKI, 1998, p.179).
}

A imprensa alternativa do período surge então neste contexto em que a esquerda brasileira, representada por intelectuais de diversas áreas de atuação, busca atuar no embate à política autoritária da ditadura brasileira com a intenção de transformar esta realidade. Soma-se a isso o trabalho dos jornalistas que, em meio a esse cenário de repressão à liberdade de imprensa, precisam buscar meios alternativos para trabalharem. A imprensa alternativa, considerando $O$ Pasquim, buscava muito mais criticar os "regimes de verdade" relacionados aos costumes do que propriamente protagonizar mudanças. Eles são claramente inspirados no movimento da contracultura americana no que diz respeito à tensão entre a liberdade em viver da forma que se achar adequado e uma vida regida por valores burgueses.

Esta característica é fortemente evidenciada por meio da linguagem utilizada pela publicação. Ainda que se trate de um material jornalístico, o Pasquim "inverte" a ordem tradicional dos jornalões na forma do texto e também no trato da informação. Além destes pontos, os personagens e as matérias fogem do tradicional, dos modelos de 
pessoas comumente retratados pelos jornais. Neste sentido, é notória a entrevista ${ }^{2}$ com Madame Satã em 05/05/71 (edição n 95), feita por Sergio Cabral, Paulo Francis, Millôr Fernandes, Chico Júnior, Paulo Garcez, Jaguar e Fortuna.

Madame Satã foi uma personalidade da vida noturna marginal no Rio Janeiro na primeira metade do século XX. Nasceu em 1900 em Glória do Goitá (PE), e faleceu no Rio, em 1976. Paulo Francis assim se refere à personagem no texto de abertura da entrevista:

[...] Satã nos impressionou bastante, porque é um tipo completamente fora do nosso âmbito de experiência. Todos nós duvidamos de tudo, inclusive de nós mesmos. Convertemos nossos superegos em catedrais em que nos ajoelhamos e pedimos perdão a nós mesmos, sem resultado. Satã tem certeza das coisas que faz. Eu disse, na entrevista, que ele me parece literatura, à parte mais sofisticado e legítimo do que Jean Genet (o que Sartre escreveria sobre ele, fico pensando). Não esconde o jogo. Se aceita como é. Há coisa mais difícil? Pra nós (um mítico nós e todos, bem entendido, mas os incluídos se reconhecerão) impossível.

Eu diria mais: que Satã representa a verdadeira contracultura brasileira, que essa que aí está, apesar de seus valores intrínsecos e universais, nos foi imposta de fora pra dentro, o que às vezes é bom, outras, não. Já Satã emergiu deste asfalto, deste clima, deste ragu cultural brasileiro, que tentamos negar inutilmente, mas que, tal qual o rio do poema de Eliot, é um deus primitivo, capaz de adormecer, apenas e sempre vivo, vingativo e traiçoeiro. A sociedade urbana, de consumo, aqui, é puro verniz, descascando visivelmente. Outras forças, suprimidas, estão aí, poderosamente latentes, acumulando impacto $[\ldots]^{3}$

A entrevista é bem peculiar, e percebe-se que os jornalistas desenvolvem a sua maneira de fazê-la tocando em assuntos e temas que em outro contexto não seriam bem vistos. Certamente que Madame Satã por si só já é uma figura emblemática pelo modo que leva a sua vida, mas a forma com que os jornalistas de $O$ Pasquim conduzem a entrevista dá a impressão de que todos estão à vontade para falar dos mais diversos temas. Selecionamos algumas perguntas e respostas para darmos um panorama disso que tratamos:

Chico - Quem é que te deu esse apelido de Madame Satã?

\footnotetext{
${ }^{2}$ A entrevista pode ser encontrada no livro O Pasquim - Antologia - 1969 - 1971 - Vol. I, organizado por Sergio Augusto e publicado pela Editora Desiderata.

${ }^{3}$ Este trecho da entrevista original foi publicado em 5 de maio de 1971, edição no 95 , páginas 2 a 7. Madame Satã foi entrevistada por Sergio Cabral, Paulo Francis, Millôr Fernandes, Chico Júnior, Paulo Garcez, Jaguar e Fortuna. A entrevista foi publicada posteriormente no livro de Fábio Altman, A Arte da entrevista, São Paulo, 1995.
} 
Esse apelido de Madame Satã ganhei em 1938, no Bloco Caçador de Veados, depois passou para Caçador da Floresta e morreu com esse nome. Depois nasceu como Turunas de Monte Alegre.

Sérgio - Mas você era caçado ou caçador?

Eu era caçador.

Chico - Mas conta a história do apelido.

Bem, havia o baile de carnaval e o concurso. Então eu me exibi com a fantasia de Madame Satã no Teatro da República e ganhei o primeiro lugar. Ganhei um tapete de mesa e um rádio Emerson, feito um balezinho, ele abria do lado, assim, feito uma portinha. O último ano que eu desfilei foi em 1941. Eu estava preso, mas anulei um processo e vim passar o carnaval na rua. Desfilei com a Dama de Vermelho.

Sérgio - O que que você acha do Clóvis Bornay?

Eu vou te explicar uma coisa: eu não tenho o que dizer dessas bichas velhas, não (AUGUSTO, 2006, p. 198). ${ }^{4}$

Até por uma questão de espaço não colocaremos a entrevista completa, mas é um material que vale a pena ser lido para se entender este aspecto "anárquico" do Pasquim. Compreendemos que o tipo de humor produzido pelo jornal é o que se aproxima do humor cínico, de negação. Mas isso não quer dizer que ele não seja libertário no sentido de valorização do sujeito e da liberdade do indivíduo. O riso, neste caso, teria a função de provocar uma espécie de antídoto contra as repressões, um riso baseado no chiste e que para Sigmund Freud (1905) representa um mecanismo de defesa do inconsciente frente às proibições da vida em sociedade. Estas limitações que o homem passa a interiorizar são amenizadas então pelas atitudes humorísticas.

O chiste seria para Freud uma espécie de brincadeira prazerosa e que precisa do outro para existir. Ele suscita o prazer ao surtir efeito em outros. Sobre o humor, mais próximo da comicidade do que o chiste, Freud traz a seguinte definição:

\begin{abstract}
O humor é um meio de obter prazer apesar dos efeitos dolorosos que interferem com ele; atua como um substitutivo para a geração desses afetos coloca-se no lugar deles. As condições para seu aparecimento são fornecidas se existe uma situação na qual, de acordo com nossos hábitos usuais, devíamos ser tentados a liberar um afeto penoso e então operam sobre estes motivos que o suprimem (FREUD, 1905, p.257).
\end{abstract}

Além de caracterizar o humor como um mecanismo de defesa, Freud também considerou os efeitos do humor: "Os processos defensivos são os correlativos psíquicos de um reflexo de fuga e realizam a tarefa de impedir a geração do desprazer a partir de fontes internas" (1905, p.262). Quando um comediante conta uma piada, começa a criar

\footnotetext{
${ }^{4}$ Esta referência, porém, foi retirada do livro: O Pasquim - Antologia - 1969 - 1971 - Vol. I, organizado por Sergio Augusto e publicado pela Editora Desiderata, páginas 198 a 202.
} 
certa tensão, que aumenta até um desfecho abrupto, revertendo as expectativas da plateia. Para isso, ele cita que o móvel do riso é "a repentina transformação de uma expectativa tensa em nada". Freud descreveu o humor como uma "ruptura de determinismo", acrescentando que esta ruptura é acompanhada de uma ruptura de previsão. Só se poderá chegar ao riso se esta for uma nova previsão tranquilizadora.

Mario Fleig, psicólogo e filósofo, considera o chiste a partir de um dos seus efeitos que é o riso:

Um chiste que precise ser explicado já não tem nada mais de chistoso, perdeu a graça. Por isso o que estamos elucidando aqui sobre o chiste não tem graça nenhuma, não nos faz rir e muito menos apresenta um lance criativo, como é peculiar ao chiste.

[...] Vejamos um singelo exemplo, referido por uma colega: Um menino, em sério conflito com seu irmão, no momento da oração, assim conclui o "Pai nosso": “... livrai-nos do mala mém." O cruzamento de duas cadeias de pensamento, uma manifesta e a outra latente, se faz pela condensação de "mal" + "mala" resultante do deslocamento do intervalo para a letra seguinte. Essa condensação permite então a irrupção da frase recalcada, reveladora dos pensamentos de agressividade endereçados ao irmão" (FLEIG, 2009, p.7).

\section{A função social e cultural do riso}

Além da compreensão do humor como manifestação do inconsciente, o humor pode ser compreendido ainda a partir de sua função social e cultural. Henri Bergson analisa o papel social do riso e considera que ele é fruto do contexto e do momento histórico em que está inserido. Assim, para se entender ou fazer parte da interferência humorística é preciso fazer parte daquele contexto. Isso pode ser observado quando determinadas expressões humorísticas "perdem” a graça em outro momento histórico.

Um exemplo é o humor visto no humorístico Casseta e Planeta, para citarmos um. Alguns fatores são elencados para explicar a "falta" de graça das edições atuais, mas a pergunta é: será que os humoristas perderam a mão no trato da crítica humorística ou de fato o cotidiano político do Brasil dá mostras diárias da comicidade sem que não haja necessidade do humor para criticá-lo?

Se o humor nasce da inversão dos valores, da destituição dos poderes, como reagir quando os poderes por si só oferecem o seu declínio por meio de declarações infelizes, comportamentos questionáveis e situações que configuram o cômico? Para Bergson, "a sociedade será engraçada quando houver, por exemplo, uma imagem que sugira a ideia de uma sociedade fantasiada, mascarada. Tudo aquilo que precisar de um disfarce, seja objeto, natureza ou a sociedade tornar-se-ia cômico" (1980, p.33). 
A visão carnavalesca do mundo, ou seja, a ideia de que é preciso desestruturar a ordem por meio do riso, é analisada por Mikhail Bakhtin. De acordo com o pensador russo, a linguagem rabelaisiana incorpora no seu contexto elementos da tradição da cultura popular da Idade Média e do Renascimento e é pautada pelos princípios estéticos do realismo grotesco. Por isso, o riso observado em Rabelais é aquele que tem a função cultural e também social de almejar uma nova vida em que tudo é permitido e não há repreensão.

Entre os elementos da visão cômica do mundo na cultura popular da Idade Média estão as festas, que dizem respeito a todo tipo de festa popular, tais como aquelas que se utilizam dos próprios elementos religiosos, tais como: a festa dos loucos, festa do asno, festa pascal. Nestas festas carnavalescas, o povo parodia a própria vida, invertendo os valores desta: uma vida melhor, livre e renovada: "O carnaval é a segunda vida do povo, baseada no princípio do riso. É sua vida de festa" (BAKTHIN, 1987, p.10). O riso festivo não é uma reação individual diante de um fato "cômico" isolado, mas tem caráter coletivo:

\begin{abstract}
O riso carnavalesco é em primeiro lugar patrimônio do povo (esse caráter popular é inerente à própria natureza do carnaval), todos riem, o riso é geral; em segundo lugar é universal, atinge a todas as coisas e pessoas (inclusive as que participam no carnaval), o mundo inteiro parece cômico e é percebido e considerado no seu aspecto jocoso, no seu alegre relativismo; por último, esse riso é ambivalente: alegre e cheio de alvoroço, mas ao mesmo tempo burlador e sarcástico, nega e afirma, amortalha e ressuscita simultaneamente (BAKTHIN, 1987, p.10).
\end{abstract}

O riso popular revelado por Bakhtin não é individual, e para demonstrar sua força deve ser coletivo, compreendido no âmbito social e universal. Não é verificado em demonstrações particulares de riso por objeto ou diante de uma situação engraçada, mas sobre o mundo todo e assim esta versão é a realidade ainda que efêmera. O riso é libertador porque instaura uma realidade desprovida da visão do sagrado e séria do mundo, brinca com a autoridade e com o medo: "É a razão pela qual o riso, menos que qualquer outra coisa, pode ser instrumento de opressão e de embrutecimento do povo. Nunca ninguém chegou a torná-lo inteiramente oficial. Ele sempre permaneceu como arma da liberdade entre as mãos do povo" (BAKHTIN, 1987, pp.101-102).

Por transitar no terreno da liberdade, o riso também sofre interdições que vão desde o desagravo à manifestação ruidosa do riso até a sua impossibilidade de 
manifestação. A primeira se situa no plano do comportamento social em que as regras de civilidade são aceitas tacitamente entre os membros pertencentes a um grupo, em que as relações de interdependência, citando Elias (1939), seriam os planos e ações isolados e não planejados "racionalmente" e que podem dar origem ao processo civilizador. A segunda diz respeito às interdições a manifestação do riso na sociedade. Neste sentido, as interdições estariam relacionadas aos temas e situações tabus com os quais não "se deve" brincar, tais como gênero, sexo, raça e religião. Quem pode provocar o riso e em que contexto também são condições que fazem parte das limitações do humor.

Sobre isso é importante destacar a revista do Instituto Humanitas-Unisinos, edição de número 367/ ano 11, de 27 de junho de 2013, que traz diversos pesquisadores, entre eles historiadores, filósofos e psicanalistas, para discutir estes e outros aspectos do riso e do humor. Dentre os textos que selecionamos na versão online da revista, está o da professora Maria Generosa Ferreira Souto, para quem as principais interdições que o riso sofreu na sociedade "partiram do princípio de que rir em praça pública ou em ritos oficiais da Igreja era proibido. O riso foi excluído e controlado" (SOUTO, p. 21).

Sobre a visão da carnavalização, Souto pontua que:

O carnaval na concepção de Bakhtin é o locus privilegiado da inversão, onde os marginalizados apropriam-se do centro simbólico e fazem explodir a alteridade, o excêntrico, o lado marginal, o periférico, o excludente mesmo. Representa, portanto, a liberdade, o extravasamento de um mundo às avessas (SOUTO,2009, p. 22).

\section{O humor e a ideia de vida-artista proposta por Michel Foucault}

Trazendo para o contexto que nos dedicamos a analisar, esta carnavalização em que impera o humor pela sátira, pela teatralização do real e inversão dos valores sociais revela um aspecto primordial do humor que é evidenciar os sujeitos e discursos marginalizados. Aquilo que não está evidente e não está posto. Entendemos que neste sentido podemos pensar o humor ou as expressões humorísticas a partir da ideia de estética da existência analisada por Michel Foucault. Para Guilherme Castelo Branco, podemos pensar a estética da existência como:

Uma forma de vida não assujeitada, não conformada com formas de vida padronizadas pelas classes pequeno-burguesas e burguesas, todas elas cerrando força no individualismo, nos interesses familiares, na obsessão pela segurança patrimonial, médica, policial, educacional, etc.; estética da 
existência e vida não conformada, portanto, estão sempre juntas (BRANCO, 2009, p.144).

O texto de Guilherme Castelo Branco faz parte das discussões presentes no livro Para uma vida não-fascista, que busca, por meio do debate com pesquisadores, analisar alguns pontos referentes ao pensamento foucaltiano no que diz respeito à necessidade de confrontar "todas as formas de fascismo, desde aquelas formas pequenas que fazem a amena tirania de nossa vidas cotidianas". Foucault, que se dedicou a analisar os funcionamentos dos mecanismos de controle do poder, as interdições nas questões relacionadas à loucura e o sexo, entre outros temas de igual importância, tem algumas de suas ideias revisitadas para se estabelecer algumas relações com aquilo que alguns autores chamam de "fascismos diários", que são exercidos e compartilhados no cotidiano.

Neste sentido, discutem-se questões ligadas ao gênero e o papel da mulher nas discussões contemporâneas, a comunicação, a dietética, a pedagogia dos corpos, entre outros. Ainda que se tratem de temas distintos, eles trazem em seu bojo o engenhoso sistema de produção de discursos midiáticos e médicos, por exemplo, na construção da ideia de corpos ideais, de comportamentos a serem seguidos e acima de tudo que represente modelo para outrem. Não basta o sujeito ter para si a conduta de vida que deseje, ele ainda deve compartilhar entre os seus e considerar que os que não o fazem não se encaixam. A reprodução dos discursos médicos em relação à dietética e corpos ideais seria aquela em que o sujeito tido como obeso carrega o estigma da falta de caráter e preguiça em mudar a sua situação. Este sujeito é achincalhado nos programas de televisão que se dedicam a emagrecê-lo, submetido a todo tipo de humilhação verbal e física de modo que quem o assiste "sabe o que espera" caso não resolva mudar a sua vida.

Neste cenário, em que os comportamentos são vigiados, dizem os autores que é preciso levantar-se e procurar novas formas de vida, não no sentido "motivacional" da palavra, como solução, mas no sentido de os sujeitos serem capazes de pensar de forma autônoma. Situamos o exercício do humor como forma de vida crítica, pensante e que não necessariamente tenha posicionamento partidário. Um autor que sempre se aproximou desta manifestação existencialista do humor foi Millôr Fernandes (19232012). É o riso que debocha de si mesmo e não acredita em nada. 


\begin{abstract}
Seu humor ia além dos marcos da crítica social da maioria dos humoristas da época, atingindo o âmbito da filosofia da vida. Mas depois do golpe militar que coincidiu com a ruptura dos Diários Associados, tornou-se engajado. Não a moda das esquerdas, a partir de uma ideologia e sim ao estilo do existencialismo sartreano, cuja pedra angular, conforme Luís Carlos Maciel, era a liberdade total da existência humana. A tese de que a existência precede a essência, negando-se o valor de toda ideia ou norma preconcebida (KUCINSKI, 2003, p.46).
\end{abstract}

Esta visão do humor funde-se com o conceito de vida-artista proposto por Foucault, que seria "uma vida generosa, ágil, que recusa as formas de vida assujeitadas da ordem burguesa. A vida-artista, portanto, é uma possibilidade real para todo sujeito ético, autônomo, com o potencial de inventar-se e à vida de outros a ele vinculado (2009, p.145).

A vida-artista e o humor unem-se pelo laço de fazer da vida e do cotidiano ferramentas para se almejar uma existência calcada na autonomia e liberdade sem que seja necessário fundamentar os seus princípios em regras de normalização, segregação ou disciplina. Tanto a vida-artista quanto o humor carregam em sua gênese a incompletude diante da vida. Sobre isso, o psiquiatra e psicanalista Abrão Slavutsky comenta em entrevista para Márcia Junges: “O humor aceita a loucura humana e sorri diante dela. Faz refletir sobre a tragédia e ainda distende os nervos do mundo. É uma vacina contra o desespero que, por doses moderadas de ceticismo, nos imuniza contra a tendência de levarmos tão a sério a seriedade dos homens" (2009, p.30).

\title{
Alguns elementos do cômico em textos humorísticos
}

De acordo com Slavutsky, ainda que o humor não provoque revoluções, ele é capaz de "estremecer" as bases do poder revelando o caráter cômico de algumas situações. Um bom exemplo são as matérias satíricas produzidas pelo blog The I-piauí Herald, que faz parte da revista Piauí. Ainda que o foco seja exclusivamente político, o blog não poupa sua "artilharia" para outras áreas como cultura, celebridades e futebol. À época da redação deste texto, o Brasil encontrava-se em meio à Copa das Confederações e protestos que reuniram centenas de manifestantes em todo o país. O mote das manifestações, que se iniciaram em São Paulo, era a redução da tarifa do ônibus na capital e somado a isso outras questões vieram à tona como o próprio evento esportivo, a corrupção, a PEC 37, entre outros. Sobre isso, o blog posiciona-se da seguinte maneira: 
FIFA aumenta o preço dos ingressos em 20 centavos

ZURIQUE - Aturdido com a recepção da torcida brasileira na abertura da Copa das Confederações, Joseph Blatter anunciou medidas para a Copa do Mundo. "As vaias estão fora do padrão FIFA e não serão permitidas no ano que vem", ressaltou. Em seguida, anunciou um aumento de 20 centavos no preço dos ingressos. "Precisamos selecionar melhor o público de uma Copa do Mundo", justificou.

Blatter revelou que a FIFA está se organizando para exigir royalties das manifestações em 2014. "De acordo com a lei geral da Copa, somente a FIFA ou empresas indicadas por ela poderão fazer jornalismo no Brasil em 2014", esclareceu. Imediatamente, a Band News contratou Dona Palmirinha para ler receitas de bolo durante todo o ano que vem.

Atento aos anseios dos jovens do século 21, Arnaldo Jabor divulgou uma mensagem em que apoiava o aumento do preço dos ingressos, a caxirola e a escalação de Hulk. Ao meio dia, mudou de ideia. No final da tarde, mudou de ideia novamente. ${ }^{5}$

Uma breve leitura deste texto, que é característico do blog, revela os pontos que mencionamos anteriormente no que diz respeito ao caráter apolítico do humor. Um manifestante que o lê dificilmente diria se tratar de um texto que faz crítica à manifestação. A figura de autoridade aqui retratada, o presidente da Fifa, não é ridicularizado, mas sim "condenado" ao escárnio pela própria declaração dada à imprensa. Convém destacarmos também o conceito de alogismo de Vladimir Propp para analisar o trecho. Segundo Propp, "ao lado do fracasso daquilo que se deseja por causas externas ou internas, há casos em que o fracasso se deve à falta de inteligência. A estultice, a incapacidade mais elementar de observar corretamente, de ligar causas e efeitos, desperta o riso" (1992, p.107).

O que se observa no texto que selecionamos é o absurdo na sentença. Propp classifica este recurso como alogismo que para ele teria dupla natureza: os homens dizem coisas absurdas ou realizam ações insensatas. O alogismo seria uma concentração errada de ideias que se expressam em palavras e este agrupamento de palavras faz rir enquanto as ações insensatas seriam as ações que são motivos de riso.

Outra manifestação humorística contemporânea no Brasil e que destaca por divulgar matérias falsas como se fossem verdadeiras é o site Sensacionalista: um jornal isento de verdade. $\mathrm{O}$ site tem um programa televisivo homônimo no canal pago Multishow que se assemelha aos telejornais convencionais na forma e na apresentação

5 Este texto foi publicado em 18 de junho de 2013 e pode ser acessado pelo link: http://revistapiaui.estadao.com.br/blogs/herald/esporte/fifa-aumenta-o-preco-dos-ingressos-em-20centavos 
das notícias. Na versão online, mesclam-se sátiras ao comportamento, as notícias do cotidiano e também os destaques em política. Por dialogar diretamente com o público da internet, muitas de suas notícias são compartilhadas nas redes sociais, e isso quer dizer que nem sempre há um filtro e muitas "notícias" são tomadas como verdadeiras.

Para citarmos um exemplo, selecionamos uma matéria que faz uma sátira à contratação de Mano Menezes para assumir o cargo de técnico no Flamengo:

\begin{abstract}
Flamengo exige que novo treinador seja chamado de professor para justificar baixo salário

Por Vinicius Antunes

"Sabemos que o clube passa por uma grave crise financeira e por isto, escolhemos a dedo um treinador que queira ser verdadeiramente professor: nada de grandes salários e ainda terá que aturar este bando de jogadores indisciplinados que temos aqui." Foi com estas palavras que o presidente do clube falou sobre a busca por treinadores. Mano Menezes virá se ganhar no máximo 30 reais a hora, é o que um professor ganha.

Pelo andar da carruagem, a Gávea ficará mesmo sem um técnico de futebol, mas já está quase apresentando um professor de língua estrangeira: "Atualmente tem bastante desses no mercado e são os que ganham um salário mais compatível. Fomos até o Fisk tentar algumas contratações e estão ganhando cerca de 15 reais a hora. Professores de geografia e física nem pensar, são difíceis de achar e vão querer cobrar um valor exorbitante acima de 30 reais que é o que podemos pagar atualmente.”6
\end{abstract}

O texto acima possui elementos claros de paradoxo e ironia. O paradoxo é um dos instrumentos cômicos definidos por Vladimir Propp e representaria a oposição do que está sendo dito. Para Propp, "próximo dos trocadilhos situam-se os paradoxos, isto é, aquelas sentenças em que o predicado contradiz o sujeito, ou a definição o que está pra ser definido" (1992, p.124). "É pertinente definir o conceito de paradoxo porque próximo dele está a ironia, enquanto no primeiro os conceitos ainda que sejam distintos são reunidos, na ironia as ideias são expressas, mas se subentende o contrário. Em outras palavras, diz-se algo positivo, pretendendo, ao contrário, expressar algo negativo, oposto ao que foi dito" ( 1992, p.125). O que pode também significar o contrário; diz-se algo negativo e em seguida "nas entrelinhas", que não deveriam estar ali escritas, a afirmação é positiva. "A ironia revela assim alegoricamente os defeitos daquele (ou daquilo) de que se fala. Ela constitui um dos aspectos da zombaria e nisto está sua comicidade" (1992, p.125).

\footnotetext{
${ }^{6}$ Este texto foi publicado em 09 de junho de 2013 e pode ser acessado por meio do link: http://www.sensacionalista.com.br/2013/06/09/flamengo-exige-que-novo-treinador-seja-chamado-deprofessor-para-justificar-baixo-salario/
} 
No texto analisado, verificamos a ironia com questões ligadas à educação no país principalmente relacionada ao baixo salário dos professores. À época da publicação do texto, uma notícia chamava a atenção para a situação dos professores em Juazeiro do Norte, que tiveram os salários reduzidos em até 40\%. A imagem da professora Antônia Lucimeire Oliveira aos prantos reforçou a indignação da classe com a situação. Em outro texto, ao referir-se às manifestações em São Paulo, é citado: "Um dos líderes do movimento, o menor J.P.S., falou sobre a manifestação". Neste caso não se sabe se a ironia é com o fato de a manifestação ser composta na sua maioria por jovens nesta faixa etária ou em referência ao posicionamento de alguns veículos da mídia em pontuar esta questão quando se trata de criminosos menores de idade nas coberturas recentes no momento em que se discute a redução da maioridade penal no país.

Este exemplo nos leva a pensar sobre as condições de existência e repercussão do humor. Entendemos que para surtir efeito é preciso considerar que a produção humorística tem vínculo com o seu tempo e contexto histórico, ou seja, algo que fez rir em determinado contexto pode não ter a menor graça em outro. O riso não se explica, se precisar ser explicado não suscitou a graça. O humor como função social sofre interdições no que diz respeito a temas-tabus dependendo da situação cultural. Podemos citar um exemplo referente à repercussão das charges publicadas na revista satírica "Charlie Hebdo", em setembro de 2012.

$\mathrm{Na}$ capa da revista sob o título de "Intouchables 2", há um desenho de um judeu ortodoxo empurrando um homem aparentemente judeu com um turbante que está numa cadeira de rodas e fala a seguinte frase em francês: "faut pas se moquer", algo como “não deveria rir”. Nas páginas internas da revista, há outras figuras e charges que inclusive trazem o profeta Maomé nu. O governo francês precisou intervir com medidas especiais de segurança em decorrência das reações de desagravo por parte dos muçulmanos. Não faltam exemplos no Brasil em que expressões humorísticas que se referem a piadas e sátiras com crianças, etnias, raça e gênero suscitam diversas reações que levam ao questionamento se o exercício do humor deve ter limites.

Além disso, há de se considerar também as condições para que o riso prospere. Henri Bergson estabelece três condicionantes para que haja o riso: 1) não há comicidade sem levar em conta aquilo que é próprio do homem em essência ou aparência; 2) o riso se dirige à inteligência pura, não pode haver emoção ou constrangimento; 3) o riso é 
essencialmente um fenômeno social e como tal precisa de meios para se propagar.

Considerando estas condições, entendemos que o humor possui características que o tornam universal, mas também que se trata de um exercício individual de transformação do pensamento. Neste sentido, o exercício do humor dialoga com a perspectiva foucaultiana proposta por Guilherme Castelo Branco, em que a luta da transformação da sociedade deve passar também pela transformação individual. "Se quisermos mudar o mundo, também temos que mudar a nós mesmos, através do incessante trabalho de superação de nossas limitações internas, de nosso egoísmo, dos nossos interesses meramente pessoais, enfim, de nossos pequenos fascismos" (2009, p.148).

\section{Considerações finais}

Abrão Slavutsky pondera na entrevista publicada pela revista da Unisinos que "no humor não há conclusões finais, lições de vida, orientações existenciais. Em todo caso, encerraria esta conversa, em que me fizeste falar muito, dizendo que a vida, como se diz, careceria de sentido sem a arte. Já uma vida sem humor teria muito significado" (2009, p. 34). O humor é uma arma simbólica contra a repressão do cotidiano e como analisado por Elias Thomé Saliba (2002) tem efeito libertador porque se não é possível mudar a história, é possível então mudar o seu sentido.

Realmente acreditamos nisso e nós mesmos, na produção deste artigo, revisitamos nosso antigo trabalho e nos deparamos com um último capítulo que flertava abertamente com a ideia de uma "sociedade humorística" proposta por Giles Lipovestky no livro A Era do Vazio (2005). Para este autor, as características do humor carnavalesco antes relegados a alguns aspectos da vida do sujeito especialmente aqueles que diziam respeito ao caráter de festa e espaço coletivo, tornaram-se um "imperativo social generalizado", uma atmosfera cool, um clima contínuo a que o indivíduo é submetido até no seu trabalho (LIPOVETSKY, 2005, p.112).

George Minois, por sua vez, pontua que a saturação dos sinais humorísticos minou a capacidade crítica desta forma de expressão invalidando os seus efeitos na sociedade pós-moderna: 
conseguem exterminar o cômico, tornando-se eles próprios cômicos. Certos políticos, tanto homens quanto mulheres, parecem mais grotescos que suas marionetes (MINOIS, 2003, p.596).

É bem verdade que à época da redação da monografia nos faltava o diálogo com outros conceitos e perspectivas e realmente nos encontrávamos em um estágio inicial de produção científica. Além disso, é preciso levar em consideração que não é muito difícil impressionar um estudante de comunicação social neste momento de sua vida. E por isso relacionamos esta experiência pessoal com nosso objeto de estudo proposto neste artigo. Da mesma maneira que o humor, a vida-artista proposta por Foucault tem o seu tempo. É preciso que o sujeito passeie por suas próprias convicções e tenha a possibilidade de vislumbrar novos caminhos, revisitar conceitos antigos e abrir-se para o novo. À época, acreditávamos que o humor "estava banalizado" dada a infinidade de manifestações humorísticas em diversos segmentos. Hoje entendemos que é aí que reside a sua graça: em pertencer a todos e a ninguém. $\mathrm{O}$ humor desenvolve-se no curso do tempo e não é estático, entendê-lo é abrir-se para uma vida autônoma, não normativa e padronizada. Uma vida-artista.

(Artigo recebido em 31/07/2013, aprovado em 18/08/2013)

\section{Referências}

BAKHTIN, Mikhail. A Cultura Popular na Idade Média e no Renascimento: o contexto de François Rabelais. Tradução de Yara Frateschi Vieira. São Paulo: Hucitec; Brasília: Editora Universidade de Brasília, 1987.

BERGSON, H. O Riso: ensaio sobre o significado do cômico. Lisboa: Guimarães Editores, 1993.

BRANCO, CASTELO, Guilherme. Anti-individualismo, vida-artista: uma análise nãofascista de Michel Foucault. In: NETO. V, Alfredo; RAGO, Margareth (Orgs.). Belo Horizonte. Autêntica Editora, 2009.

FLEIG, Mario. O riso e o hiato da condição humana. Revista do Instituto Humanitas Unisinos [on-line]. Edição 367: São Leopoldo, 2011. Revista IHU Online. Disponível em: http://www.ihuonline.unisinos.br/media/pdf/IHUOnlineEdicao367.pdf ISSN 19818793. 
FREUD, S. Os chistes e sua relação com o inconsciente. In: Obras Completas, vol. VIII, Rio de Janeiro: Imago, 1996.

KUCINSKI, Bernardo. Jornalistas e Revolucionários: nos tempos da imprensa alternativa. São Paulo, Edusp, 2003.

LIPOVETSKY, Gilles. A era do vazio: ensaios sobre o individualismo. São Paulo: Manole, 2005.

MINOIS, Georges. História do riso e do escárnio. São Paulo: Unesp, 2003.

PROPP, V. Comicidade e Riso. Trad. Aurora Fornoni Bernardini e Homero Freitas de Andrade. São Paulo: Ática, 1992.

SALIBA, Elias Thomé. Raízes do riso: a representação humorística na história brasileira. São Paulo: Companhia das Letras, 2002.

SLAVUTSKY, Abrão. Uma vacina contra o desespero. Revista do Instituto Humanitas Unisinos [on-line]. Edição 367: São Leopoldo, 2011. Revista IHU Online. Disponível em: http://www.ihuonline.unisinos.br/media/pdf/IHUOnlineEdicao367.pdf ISSN 19818793.

SOUTO, F, Generosa. O riso e suas interdições na sociedade. Revista do Instituto Humanitas Unisinos [on-line]. Edição 367: São Leopoldo, 2011. Revista IHU Online. Disponível em: http://www.ihuonline.unisinos.br/media/pdf/IHUOnlineEdicao367.pdf ISSN 1981-8793.

Revista do Instituto Humanitas Unisinos [on-line]. Edição 367: São Leopoldo, 2011. Revista IHU Online. Disponível em: http://www.ihuonline.unisinos.br/media/pdf/IHUOnlineEdicao367.pdf ISSN 19818793. 